LA--9466-HS-Rev.

DE83 007125

\title{
Los Alamos National Laboratory Building Cost Index
}

Hugh D. Orr

Glenn D. Lemon

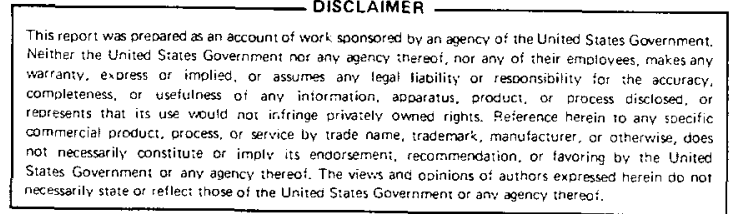

This document is

PUBLICLY RELEASABLE

3 Stenlo

Authorizing Official

Date:

$1.31-07$

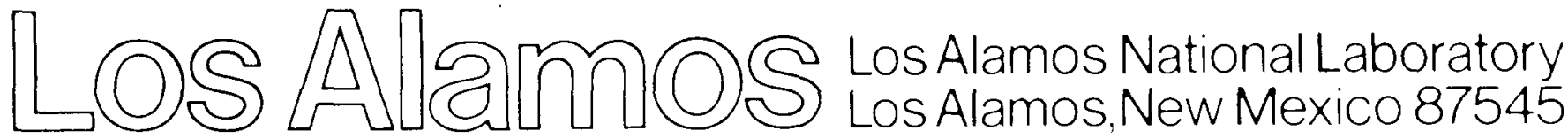




\section{DISCLAIMER}

This report was prepared as an account of work sponsored by an agency of the United States Government. Neither the United States Government nor any agency Thereof, nor any of their employees, makes any warranty, express or implied, or assumes any legal liability or responsibility for the accuracy, completeness, or usefulness of any information, apparatus, product, or process disclosed, or represents that its use would not infringe privately owned rights. Reference herein to any specific commercial product, process, or service by trade name, trademark, manufacturer, or otherwise does not necessarily constitute or imply its endorsement, recommendation, or favoring by the United States Government or any agency thereof. The views and opinions of authors expressed herein do not necessarily state or reflect those of the United States Government or any agency thereof. 


\section{DISCLAIMER}

Portions of this document may be illegible in electronic image products. Images are produced from the best available original document. 


\title{
LOS ALAMOS NATIONAL LABORATORY BUILDING COST INDEX
}

\author{
by
}

\author{
Hugh D. Orr and Glenn D. Lemon
}

\begin{abstract}
The Los Alamos National Laboratory Building Cost Index indicates that actual escalation since 1970 is near $10 \%$ per year. Therefore, the Laboratory will continue using a $10 \%$ per year escalation rate for construction estimates through 1985 and a slightly lower rate of $8 \%$ per year from 1986 through 1990.

The computerized program compares the different elements involved in the cost of a "typical" construction project, which for our purposes, is a complex of office buildings and experimental laboratories.

The input data used in the program consist primarily of labor costs and material and equipment costs. The labor costs are the contractual rates of the crafts workers in the Los Alamos area. For the analysis, 12 field-labor craft categories are used; each is weighted corresponding to the labor craft distribution associated with the "typical" construction project. The materials costs are current Los Alamos prices. Additional information sources include material and equipment quotes obtained through conversations with vendors and from trade publications. The material and equipment items separate into 17 categories for the analysis and are weighted corresponding to the material and equipment distribution associated with the "typical" construction project.

The building cost index is compared to other national building cost indexes.
\end{abstract}

\section{INTRODUCTION}

The Cost Engineering Group at the Laboratory developed a Building Cost Index to be used in the cost evaluations of construction projects at Los Alamos, New Mexico. In the development of this index, local conditions and the specific nature of construction at the Laboratory were evaluated to generate estimate figures required for the analysis. Three types of construction (an electronic or chemical laboratory, a special experimental laboratory, and an office complex) were taken from an actual construction project. The project was analyzed using weighted averages for materials, equipment, and crafts labor. Materials and equipment break down into 17 categories, and over 600 separate items are catalogued in the data files; 12 field-labor crafts are analyzed separately. The computer program, developed at the Laboratory to handle this data, gives the logarithmic exponent of change from a 1970 baseline and calculates the price-line rise (or decline). Cost of each category of material or equipment and each field-labor craft is analyzed. then combined with all other categories to produce the composite index. (See Figs. I and 2). 


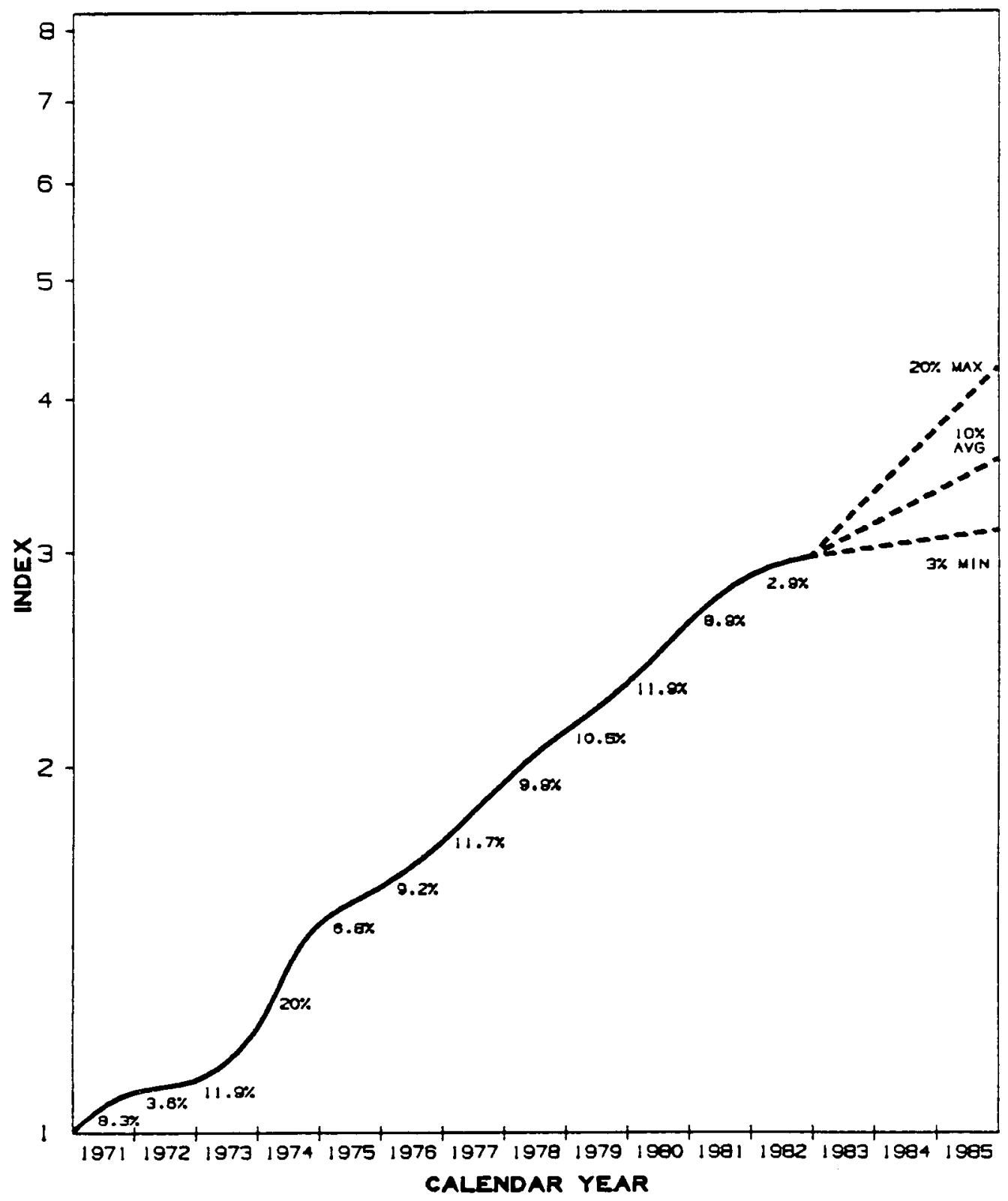

Fig. I. Los Alamos National Laboratory Building Cost Index.

The analysis evaluates each item in a category and establishes a cost index for that category beginning with 1.0 in 1970. Likewise, it evaluates each category's cost index in relation to its corresponding weighted factor and establishes a total cost index or escalation rate for labor, materials, and the "typical" construction project.

The forecasting portion of the Los Alamos National Laboratory Building Cost Index utilizes the above historical economic price and wage behavior to establish a vigorous economic structural specification. 


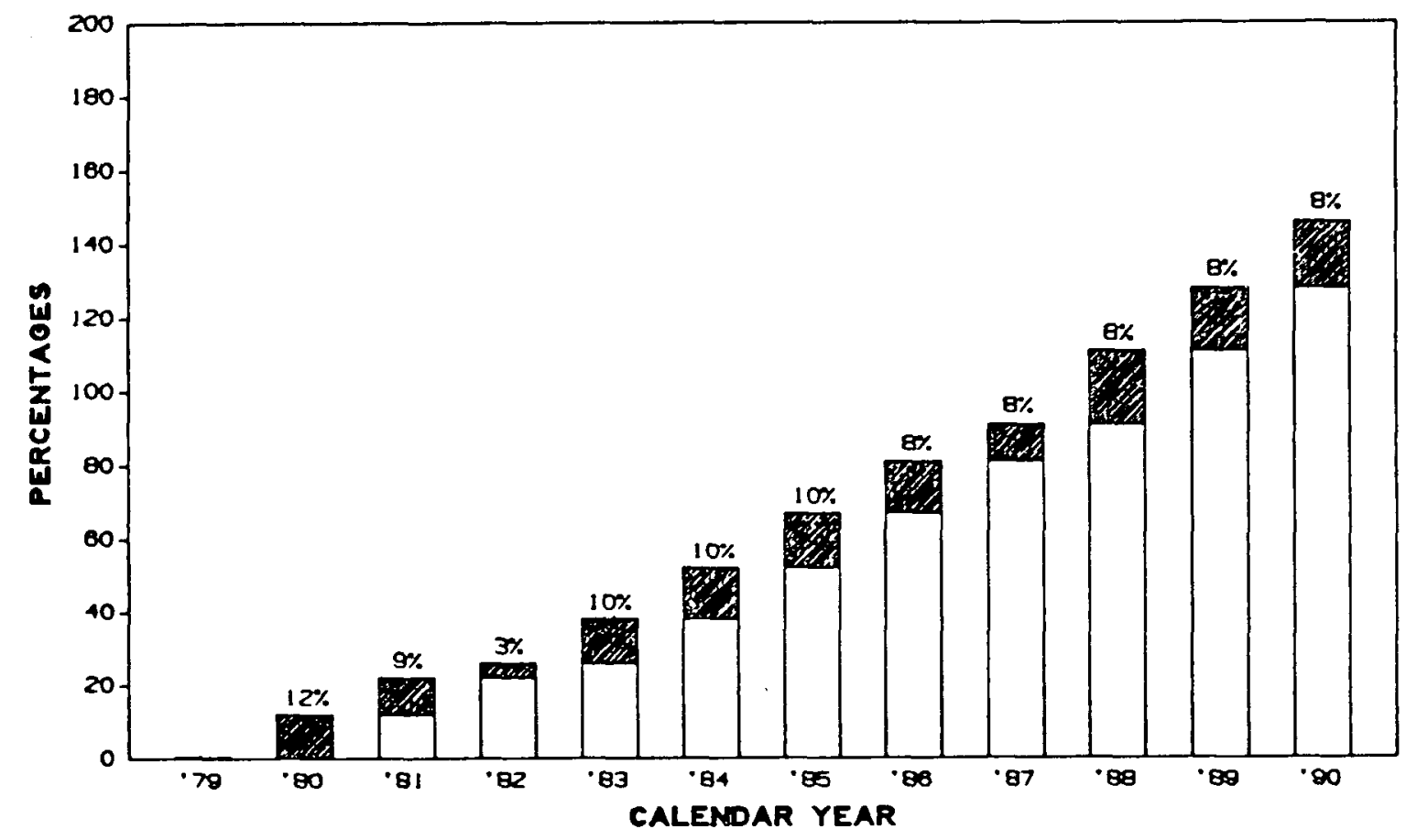

Fig. 2. Los Alamos National Laboratory Building Cost Index projection for the 1980s. Excludes unusual expenditures for experimental equipment.

The analysis evaluates each item in a category and establishes a cost index for that category beginning with 1.0 in 1970. Likewise, it evaluates each category's cost index in relation to its corresponding weighted factor and establishes a total cost index or escalation rate for labor, materials, and the "typical" construction project. The current total project cost index is 2.9015 , which is an average escalation rate of $10.17 \%$ per year for the past 11 years.

\section{CONSTRUCTION FIELD-LABOR INDEX}

The Construction Field-Labor Index developed at the Laboratory represents field-labor cost increases for new construction in the Los Alamos area. The index is based on costs for the 12 most common fieldlabor crafts. A man-hour distribution was extracted from the "typical" project estimate to determine the relative cost of each craft group and to isolate the effects of varying percentage wage changes negotiated by each craft. The list of crafts and the percentage distribution follows.

$\begin{array}{llll}\text { Electricians and linemen } & 18.3 \% & \text { Masons } & 6.4 \% \\ \text { Laborers } & 16.6 & \text { Tinners } & 4.6 \\ \text { Carpenters } & 16.0 & \text { Operators } & 4.0 \\ \text { Pipefitters and plumbers } & 13.6 & \text { Roofers } & 2.3 \\ \text { Ironworkers } & 8.6 & \text { Teamsters } & 2.0 \\ \text { Painters } & 7.5 & \text { Insulators } & 0.1\end{array}$

The Construction Field-Labor Index is the stable component of the Building Index. Each craft union writes into its contract a specific wage change. These contracts are renegotiated at regular intervals and are relatively predictable from year to year. 


\section{MATERIAL AND EQUIPMENT INDEX}

The Material and Equipment Index developed at the Laboratory represents the materials price changes on new construction of Laboratory buildings during the last 12 years. The index is based on the 17 categories of materials and equipment most heavily used in new construction at Los Alamos. A dollar cost distribution was extracted from the "typical" construction project estimate in order to determine the relative importance of each category and its percentage distribution.

$\begin{array}{lcll}\text { Miscellaneous steel } & -27.5 \% & \text { Process equipment } & 3.1 \\ \text { Electrical equipment } & 16.6 & \text { Cast iron pipe } & 3.0 \\ \text { Wiring, cable, and conduit } & 8.2 & \text { Insulation } & 3.0 \\ \text { Pipe fitting } & 7.8 & \text { Lumber } & 2.2 \\ \text { Cement products } & 8.3 & \text { Pumps } & 2.1 \\ \text { Laboratory furniture } & 4.9 & \text { Instruments } & 1.0 \\ \text { Fans and blowers } & 4.2 & \text { Air compressors } & 0.5 \\ \text { Structural steel } & 4.0 & \text { Heat exchangers } & 0.1 \\ \text { Tanks and vessels } & 3.5 & & \end{array}$

The Material and Equipment Index actually comprises 17 different categories, which, in turn, are composites of many individual item costs. Collecting and analyzing information on many different items in each category makes each category less sensitive to changes in any one item. The factor for each material category represents cost trends rather than actual price changes. Because actual dollar values on items varied greatly within a category, the cost factor of each item was indexed to help compare histories and arrive at a trend. A linear average of the indexes in a category was computed.

The Material and Equipment Index is the changeable part of the Building Cost Index. Materials prices change daily and reflect the traffic that the market will bear; they are also sensititive to quantity discounts, seasonal changes, purchase frequency, stock inventory, and product availability.

\section{COMPARISON OF INDEXES}

The Building Cost Index, determining the cost trends occurring at the Laboratory in Los Alamos, was compared with national cost trends. The comparison is based on data published in Engineering News Records (ENR), which is adjusted to a 1970 base year. Each index shown represents a particular type of structure or structures and a particular region of the country.

The Laboratory Building Cost Index is an input index with a broad labor base (12 crafts) and a representative material and equipment base ( 17 categories), characteristic of the office-research facilities at the Laboratory. The ENR Construction Cost Index is also an input index based on 68.38 hours of skilled labor, 25 hundredweight of standard structural steel shapes, 22.56 hundredweight of Portland cement, and 1088 board feet of $2 \times 4$ lumber. The Austin Index represents the cost changes in one type of industrial building in the central and eastern United States. The Fruin-Colnon Index represents the cost increases in five types of industrial buildings in the St. Louis, Missouri, area. The Turner Index represents cost increases in general office buildings in the major cities of the United States. Figure 3 compares the indexes. 


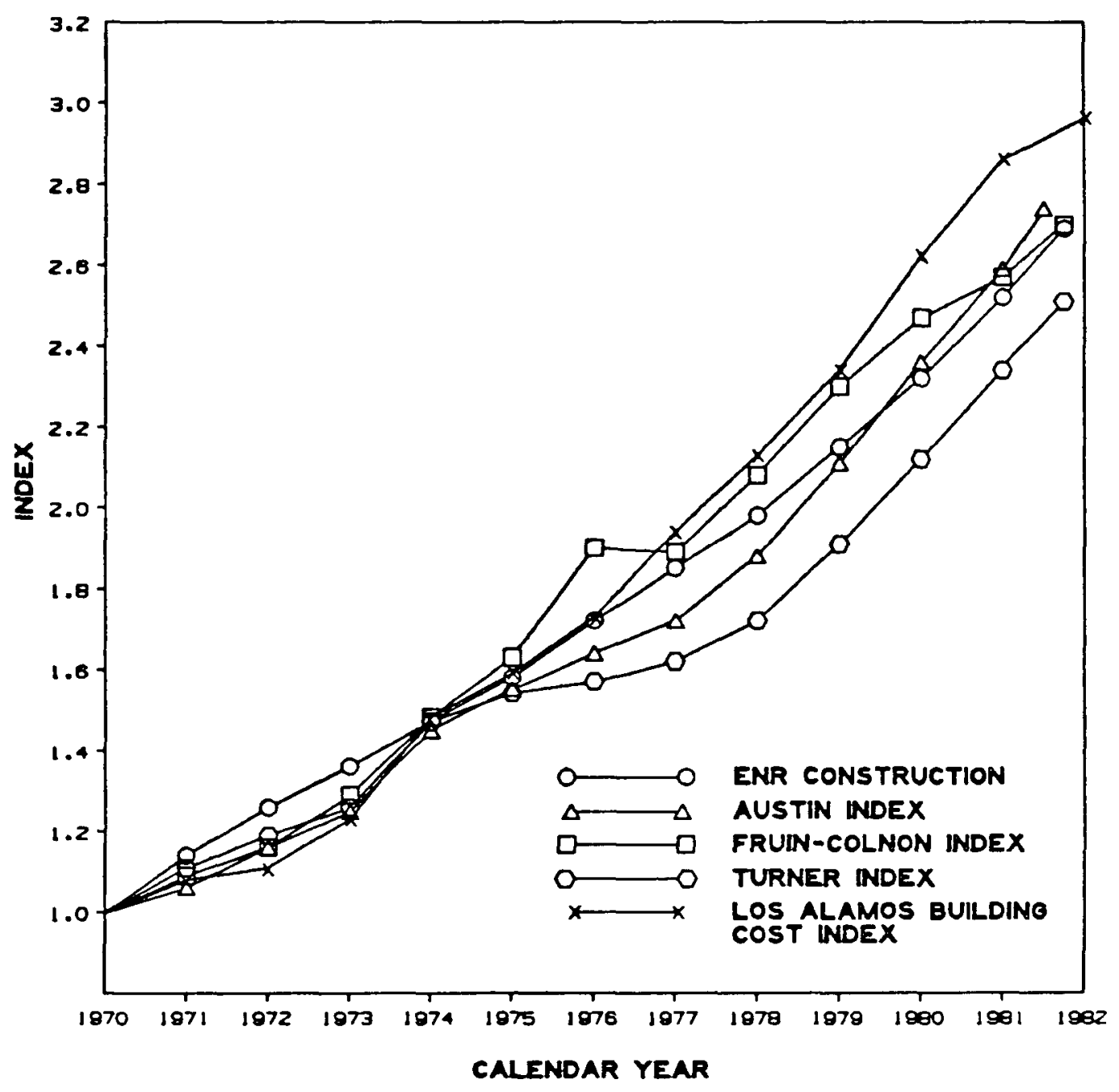

Fig. 3. Comparison of building cost indexes.

\section{ACKNOWLEDGMENTS}

Estimated increases for 1982 through 1990 were obtained from several sources. The Zia Company provided estimated labor cost. Projected increases for material and equipment were obtained through conversations with vendors and with local Laboratory and Zia purchasing personnel. Information from trade publications was used to supplement data in both the labor and material and equipment categories. 